\title{
Roles of Gender in Agriculture and Livestock Production among Tribal Farm Families in Lunglei District of Mizoram in North East Region, India
}

\author{
Senjit Singh Ashem ${ }^{1 *}$, Tarun Kumar Das ${ }^{2}$, Prabhat Kumar Pal ${ }^{2}$ and Lalmuanzovi ${ }^{1}$ \\ ${ }^{1}$ Krishi Vigyan Kendra Lunglei District, Mizoram, India \\ ${ }^{2}$ Department of Agricultural Extension, Uttar Banga Krishi Viswavidyalaya, Coochbehar, \\ West Bengal, India \\ *Corresponding author
}

\section{A B S T R A C T}

\begin{tabular}{|c|}
\hline Keywords \\
\hline $\begin{array}{l}\text { Tribal, Gender, } \\
\text { Men, Women, Farm } \\
\text { families, Role }\end{array}$ \\
\hline Article Info \\
\hline $\begin{array}{l}\text { Accepted: } \\
\text { 15 July } 2018 \\
\text { Available Online: } \\
10 \text { August } 2018\end{array}$ \\
\hline
\end{tabular}

\section{Introduction}

In India, most of the farm families are primarily engaged in farming (Singh and Chauhan, 2011); and agriculture is the most primitive occupation of Indian tribal people (Ghosh et al., 2010). The state of Mizoram is one of the eight sisters of North-East India and mostly dominated by the Mizo tribe. The area is characterized by the hilly rugged terrain. The parallel structural hill ranges run North to South direction tapering at both ends with alternating narrow valleys. The ridges show serrated tops which are highly dissected and separated by intervening ' $\mathrm{V}$ ' shaped valleys. Besides these hill ranges, there are small and limited hill ranges and numerous dissected low hills in the western part of the area.

Hill side slopes are steep and escarpments are common. The agricultural land is mostly rainfed (having only 15\% of total cultivated land under irrigation). Due to suitable climatic condition almost, all types of crops can be cultivated here. Among the tribal families, men and women of all ages and ethnic groups 
have a vested interest in agriculture (Nidhees, 2010). Mizos are not the exception of this scenario.

Livestock production is directly or indirectly connects with agriculture in rural economy. Animal husbandry is a potential employment income generating option for the rural poor particularly small and marginal farmers (Singh and Chauhan, 2012). Generally small tribal farm families rear milch animals, pigs, poultry birds for nutrient supplement through production of milk, meat and eggs; and as alternative source of income; and dogs for night watching of his house or farm.

In a farm family, women play an important role in family maintenance, farm production, post-harvest management, livestock production, and allied activities. Role and contribution of women is very crucial not only in enhancing the crop production but also in overall agricultural diversification (Bihari et al., 2012). In this backdrop, the study was conducted to assess the contribution and role of tribal men and women in agriculture and livestock production in a farm family.

\section{Materials and Methods}

\section{The study site}

The study was conducted in two villages namely Hnahthial (Latitude $22^{0} 58.453 \mathrm{~N}$ and Longitude $92^{0} 55.722^{\prime} \mathrm{E}$ ) and Thiltlang village (Latitude 2300'196' $\mathrm{N}$ and Longitude $92^{0} 55^{\prime} 374^{\prime}$ 'E) in Lunglei district of Mizoram in January to March, 2017. The villages received annual rainfall of 1698.66 - 2098mm with an altitude range from $35-1758 \mathrm{~m}$ above MSL. The main livelihoods of both the villages were based on the agriculture and animal husbandry-based occupations. Alike other states of North-Eastern parts of India, the women folklore also had a dominating role in livelihood activities in Mizoram (Fig. 1).

\section{Selection of villages and respondents}

The villages were selected purposively taking the consideration that those would be tribal villages with agriculture and animal husbandry-based livelihood systems. 80 numbers of tribal farm families involved in agriculture and livestock rearing were selected randomly taking 40 families from each village.

\section{Collection of information}

An interview schedule was designed to collect the needful information for the study. The data were collected through personal interview of the respondents.

The collected data was tabulated and analyzed in terms of frequency and percentage.

\section{Measurement scale and processing of data}

The socio-economic scale developed by previous authors (Parikh and Trivedi, 1964; Kuppuswamy, 1981; Agarwal, 2008) with allowable modification befitted for the study were used. The participation in different agricultural and animal husbandry practices were measured against a 3-point ordinal scale having "Predominantly participated", "Jointly participated" and "No participation" as scale points with 2,1 and 0 respectively.

For assessing the extent of participation, a Participation Index developed by Gupta and Pal (2006) were used as follows:

Participation Index $=\frac{2 a 1+a 2}{2 n}$

Where,

$\boldsymbol{a} \mathbf{1}=$ No. of activities undertaken independently

$a 2=$ No. of activities undertaken jointly 
$n=$ Total no. of activities

For comparison between villages and genders $\chi 2$ statistics and Wilcoxon Signed Rank test were employed.

\section{Results and Discussion}

Socio-economic and personal characteristics of farm families under study

The above Table 1 shows that in both the villages majority $(95.0 \%$ and $87.50 \%$ ) of the respondents had nuclear family and mainly depend on faming (65.00\% and 67.00\%). Livestock rearing were also taken as primary occupation by $27.50 \%$ and $25.00 \%$ families. The Chi-square values for all these cases are significant $(p<.001)$ which signifies that the two villages are not at par in distribution of families in respect of family type and primary occupation.

It is also found that $60.00 \%$ and $77.50 \%$ of the respondent families had land holding between 1.5 and 2.5 ha, whereas only $10.00 \%$ and $7.50 \%$ of the respondents had above 2.5 hectare of land in the selected villages. Majority of the respondents $(92.50 \%$ and $72.50 \%$ ) were having membership of any social organization like Self-Help Groups or Farmers' Club. Here also in both the cases Chi-square is significant at $\mathrm{p}<.001$ level, viz. the two villages are different in distribution of families in respect of land holding and social participation.

The data in Table 2 shows that majority $(52.50 \%$ and $72.50 \%)$ of the respondents belonged to middle age group having education level upto middle school $(52.50 \%$ and $40.00 \%$ ). It is also revealed that $47.50 \%$ and $52.50 \%$ of the respondents received the information though State extension system whereas $42.50 \%$ and $40.00 \%$ of the respondents were through KVK functionaries. The $\chi 2$ (Chi-square)-values indicates that in both the cases the two study villages were heterogeneous according to age distribution, land holding and usage of information sources.

\section{Gender participation in different activities of agriculture and livestock rearing}

The result in the Table 3 shows that regarding different activities in agriculture female participation is more in case of uprooting of seedlings for planting (Participation Index $=0.84$ against 0.16 of male); transplanting/ sowing of seedlings to main field (Participation Index $=0.86$ against 0.14 of male); weeding and intercultural operations (Participation Index $=0.85$ against 0.15 of male); cutting/ harvesting of the crops (Participation Index $=0.83$ against 0.17 of male) and carrying of plants to threshing floor (Participation Index $=0.78$ against 0.22 of male). All other activities although are predominantly undertaken by the male, but it is seen that Wilcoxon ( $\mathrm{Z}$ )-value is not significant $(p=.480)$ which indicates that although there is difference in participation level in individual activities but on an average participation level of female and male are statistically at par.

The result in the Table 4 shows that in livestock rearing activities female participation is more in case of feeding of poultry birds (Participation Index $=0.84$ against 0.16 of male); Watering of animals/poultry birds (Participation Index $=0.53$ against 0.47 of male) and produces separate for household consumption floor (Participation Index $=0.83$ against 0.18 of male). All other activities although are predominantly undertaken by the male, but it is seen that Wilcoxon (Z)-value is not significant $(\mathrm{p}=0.124)$ which indicates that although there is difference in participation level in individual activities but on an average participation level of female and male are statistically at par. 
Table.1 Distribution of farm families according to socio-economic characters

\begin{tabular}{|c|c|c|c|}
\hline Class & $\begin{array}{c}\text { Hnahthial } \\
\text { village }(\mathrm{N}=40)\end{array}$ & $\begin{array}{l}\text { Thiltlang village } \\
\qquad(\mathrm{N}=40)\end{array}$ & Statistical implication \\
\hline \multicolumn{4}{|c|}{ Family type(Scale: Nos.of family members) } \\
\hline Nuclear & $38(95.00)$ & $35(87.50)$ & \multirow{2}{*}{$\begin{array}{c}\chi 2(\text { Chi-square })= \\
180.35 \\
\text { p }<.001\end{array}$} \\
\hline Joint & $2(5.00)$ & $5(12.50)$ & \\
\hline \multicolumn{4}{|c|}{ Primary Occupation (Scale: Occupation from which maximum income comes) } \\
\hline Farming & $26(65.00)$ & $27(67.50)$ & \multirow{3}{*}{$\begin{array}{c}\chi 2(\text { Chi-square })= \\
180.02 \\
\mathrm{p}<.001\end{array}$} \\
\hline Livestock & $11(27.50)$ & $10(25.00)$ & \\
\hline Others & $3(7.50)$ & $3(7.5)$ & \\
\hline \multicolumn{4}{|c|}{ Land Holding (Scale: Area in hectare) } \\
\hline Upto 1.0 ha & $12(30.00$ & $6(15.00)$ & \multirow{3}{*}{$\begin{array}{c}\chi 2(\text { Chi-square })= \\
180.76 \\
p<.001\end{array}$} \\
\hline$>1.0-2.5$ & $24(60.00)$ & $31(77.50)$ & \\
\hline$>2.5$ & $4(10.00)$ & $3(7.50)$ & \\
\hline \multicolumn{4}{|c|}{ Social Participation (Scale: Membership of social organisation) } \\
\hline Member & $37(92.50)$ & $29(72.50)$ & \multirow{2}{*}{$\begin{array}{c}\chi 2(\text { Chi-square })= \\
181.39 \\
\mathrm{p}<.001\end{array}$} \\
\hline $\begin{array}{l}\text { Non- } \\
\text { member }\end{array}$ & $3(7.50)$ & $11(27.50)$ & \\
\hline
\end{tabular}

Table.2 Distribution of respondents according to their personal characters

\begin{tabular}{|l|c|c|c|c|}
\hline \multicolumn{1}{|c|}{ Class } & $\begin{array}{c}\text { Hnahthial } \\
\text { village(N=40) }\end{array}$ & $\begin{array}{c}\text { Thiltlang village } \\
(\mathbf{N = 4 0 )}\end{array}$ & Statistical implication \\
\hline \multicolumn{2}{|c|}{ Age group(Scale: Chronological age rounded to nearer integer in yrs) } \\
\hline Young (upto 30 yrs) & $3(7.5)$ & $2(5.0)$ & $\chi 2$ (Chi-square) $=$ \\
\hline Middlle aged (31-50) & $21(52.50)$ & $29(72.50)$ & 180.86 \\
$\mathrm{p}<.001$
\end{tabular}


Table.3 Distribution of men and women farmers participating different agricultural activities (expressed in frequency and percentage)

\begin{tabular}{|c|c|c|c|c|c|}
\hline Activity & $\begin{array}{l}\text { Predominantly } \\
\text { by Male }\end{array}$ & $\begin{array}{c}\text { Predominantly } \\
\text { by Female }\end{array}$ & Joint & $\begin{array}{c}\text { Male } \\
\text { Participation } \\
\text { Index }\end{array}$ & $\begin{array}{c}\text { Female } \\
\text { Participation } \\
\text { Index }\end{array}$ \\
\hline $\begin{array}{l}\text { Ploughing } \\
\text { operation for main } \\
\text { field and seed bed } \\
\text { preparation }\end{array}$ & $74(92.50)$ & - & $6(7.5)$ & 0.96 & 0.04 \\
\hline $\begin{array}{l}\text { Sorting and } \\
\text { selection of healthy } \\
\text { seeds for sowing } \\
\end{array}$ & $15(18.75)$ & $11(13.75)$ & $\begin{array}{c}54 \\
(67.50)\end{array}$ & 0.53 & 0.48 \\
\hline $\begin{array}{l}\text { Nursery raising and } \\
\text { management } \\
\text { operations }\end{array}$ & $65(81.25)$ & $6(7.50)$ & $9(11.25)$ & 0.87 & 0.13 \\
\hline $\begin{array}{l}\text { Uprooting of } \\
\text { seedlings for } \\
\text { planting } \\
\end{array}$ & $7(8.75)$ & $61(76.25)$ & $\begin{array}{c}12 \\
(15.00)\end{array}$ & 0.16 & 0.84 \\
\hline $\begin{array}{l}\text { Transplanting/ } \\
\text { sowing of seedlings } \\
\text { to main field }\end{array}$ & $9(11.25)$ & $67(83.75)$ & $4(5.00)$ & 0.14 & 0.86 \\
\hline $\begin{array}{l}\text { Application of } \\
\text { insecticide and } \\
\text { plant protection } \\
\text { measures } \\
\end{array}$ & $73(91.25)$ & $7(8.75)$ & - & 0.91 & 0.09 \\
\hline $\begin{array}{l}\text { Irrigation / } \\
\text { Watering of plants }\end{array}$ & $71(88.75)$ & $4(5.00)$ & $5(6.25)$ & 0.92 & 0.08 \\
\hline $\begin{array}{l}\text { Weeding and } \\
\text { intercultural } \\
\text { operations } \\
\end{array}$ & $7(8.75)$ & $63(78.75)$ & $\begin{array}{c}10 \\
(12.50)\end{array}$ & 0.15 & 0.85 \\
\hline $\begin{array}{l}\text { Application of } \\
\text { FYM/ fertilizers } \\
\text { management } \\
\end{array}$ & $59(73.75)$ & $15(18.75)$ & $6(7.50)$ & 0.78 & 0.23 \\
\hline $\begin{array}{l}\text { Decision making of } \\
\text { farm enterprises }\end{array}$ & $6(7.50)$ & $2(2.50)$ & $\begin{array}{c}72 \\
(90.00)\end{array}$ & 0.53 & 0.48 \\
\hline $\begin{array}{l}\text { Cutting/ harvesting } \\
\text { of the crops }\end{array}$ & $12(15.00)$ & $65(81.25)$ & $3(3.75)$ & 0.17 & 0.83 \\
\hline $\begin{array}{l}\text { Carrying of plants } \\
\text { to threshing floor }\end{array}$ & $14(17.50)$ & $59(73.75)$ & $7(8.75)$ & 0.22 & 0.78 \\
\hline \multicolumn{4}{|c|}{ Average Participation Index } & 0.53 & 0.47 \\
\hline
\end{tabular}


Table.4 Distribution of men and women farmers participating different Livestock/poultry rearing activities

\begin{tabular}{|c|c|c|c|c|c|}
\hline Activity & $\begin{array}{c}\text { Predominantly } \\
\text { by Male }\end{array}$ & $\begin{array}{l}\text { Predominantly } \\
\text { by Female }\end{array}$ & Joint & \begin{tabular}{|c} 
Male \\
Participation \\
Index
\end{tabular} & $\begin{array}{c}\text { Female } \\
\text { Participation } \\
\text { Index }\end{array}$ \\
\hline $\begin{array}{l}\text { Decision making } \\
\text { in } \\
\text { livestock/poultry } \\
\text { management }\end{array}$ & $16(20.00)$ & $5(6.25)$ & $\begin{array}{c}59 \\
(73.75)\end{array}$ & 0.57 & 0.43 \\
\hline $\begin{array}{l}\text { Collection of } \\
\text { fodder/feeds for } \\
\text { livestock } \\
\text { consumption }\end{array}$ & $57(71.25)$ & $14(17.50)$ & $\begin{array}{c}9 \\
(11.25)\end{array}$ & 0.77 & 0.23 \\
\hline $\begin{array}{l}\text { Grazing of } \\
\text { animals in field }\end{array}$ & $51(63.75)$ & $25(31.25)$ & $4(5.00)$ & 0.66 & 0.34 \\
\hline $\begin{array}{l}\text { Feeding of poultry } \\
\text { birds }\end{array}$ & $5(6.25)$ & $59(73.75)$ & $\begin{array}{c}16 \\
(20.00)\end{array}$ & 0.16 & 0.84 \\
\hline Milking of animal & $51(63.75)$ & $23(28.75)$ & $6(7.50)$ & 0.68 & 0.33 \\
\hline $\begin{array}{l}\text { Watering of } \\
\text { animals/poultry } \\
\text { birds }\end{array}$ & $11(13.75)$ & $16(20.00)$ & $\begin{array}{c}53 \\
(66.25)\end{array}$ & 0.47 & 0.53 \\
\hline $\begin{array}{l}\text { Care of } \\
\text { livestock/poultry } \\
\text { in } \\
\text { breeding/hatching } \\
\text { etc }\end{array}$ & $14(17.50)$ & $9(11.25)$ & $\begin{array}{c}57 \\
(71.25)\end{array}$ & 0.53 & 0.47 \\
\hline $\begin{array}{l}\text { Health Care of } \\
\text { sick animals/ birds }\end{array}$ & $9(11.25)$ & $5(6.25)$ & $\begin{array}{c}66 \\
(82.50)\end{array}$ & 0.53 & 0.48 \\
\hline $\begin{array}{l}\text { Shed } \\
\text { management/ } \\
\text { cleaning }\end{array}$ & $69(86.25)$ & $3(3.75)$ & $\begin{array}{c}8 \\
(10.00)\end{array}$ & 0.91 & 0.09 \\
\hline $\begin{array}{l}\text { Animal/poultry } \\
\text { waste } \\
\text { management }\end{array}$ & $65(81.25)$ & $4(5.00)$ & $\begin{array}{c}11 \\
(13.75)\end{array}$ & 0.88 & 0.12 \\
\hline $\begin{array}{l}\text { Produces separate } \\
\text { for household } \\
\text { consumption }\end{array}$ & $11(13.75)$ & $63(78.75)$ & $6(7.50)$ & 0.18 & 0.83 \\
\hline $\begin{array}{l}\text { Consult with } \\
\text { Veterinary service } \\
\end{array}$ & $61(76.25)$ & $17(21.25)$ & $2(2.50)$ & 0.78 & 0.23 \\
\hline $\begin{array}{l}\text { Purchase and sale } \\
\text { of animals }\end{array}$ & $18(22.50)$ & $9(11.25)$ & $\begin{array}{c}53 \\
(66.25)\end{array}$ & 0.63 & 0.37 \\
\hline \multicolumn{4}{|c|}{ Average Participation Index } & 0.59 & 0.41 \\
\hline
\end{tabular}


Table.5 Distribution of men and women farmers participating different post-harvest and marketing activities

\begin{tabular}{|c|c|c|c|c|c|}
\hline Activity & $\begin{array}{l}\text { Predominantly } \\
\text { by Male }\end{array}$ & $\begin{array}{l}\text { Predominantly } \\
\text { by Female }\end{array}$ & Joint & $\begin{array}{c}\text { Male } \\
\text { Participation } \\
\text { Index }\end{array}$ & $\begin{array}{l}\text { Female } \\
\text { Participation } \\
\text { Index }\end{array}$ \\
\hline $\begin{array}{l}\text { Threshing of harvest } \\
\text { products }\end{array}$ & $71(88.75)$ & $2(2.50)$ & $7(8.75)$ & 0.93 & 0.07 \\
\hline $\begin{array}{l}\text { Winnowing of harvest } \\
\text { products }\end{array}$ & $63(78.75)$ & $6(7.50)$ & $\begin{array}{c}11 \\
(13.75)\end{array}$ & 0.86 & 0.14 \\
\hline $\begin{array}{l}\text { Cleaning of harvest } \\
\text { products }\end{array}$ & $4(5.00)$ & $69(86.25)$ & $7(8.75)$ & 0.09 & 0.91 \\
\hline $\begin{array}{l}\text { Bagging of harvest } \\
\text { products }\end{array}$ & $73(91.25)$ & $2(2.50)$ & $5(6.25)$ & 0.94 & 0.06 \\
\hline $\begin{array}{l}\text { Carrying of harvests } \\
\text { products to store } \\
\text { house }\end{array}$ & $9(11.25)$ & $5(6.25)$ & $\begin{array}{c}66 \\
(82.50)\end{array}$ & 0.53 & 0.48 \\
\hline $\begin{array}{l}\text { Drying of harvest } \\
\text { products }\end{array}$ & $8(10.00)$ & $57(71.25)$ & $\begin{array}{c}15 \\
(18.75)\end{array}$ & 0.19 & 0.81 \\
\hline $\begin{array}{l}\text { Milling of harvest } \\
\text { products }\end{array}$ & $9(11.25)$ & $67(83.75)$ & $4(5.00)$ & 0.14 & 0.86 \\
\hline Processing of produce & $3(3.75)$ & 65 (81.25) & $12(15)$ & 0.11 & 0.89 \\
\hline $\begin{array}{l}\text { Retention for } \\
\text { consumption and } \\
\text { household } \\
\text { consumption } \\
\end{array}$ & $2(2.50)$ & $7(8.75)$ & $\begin{array}{c}71 \\
(88.75)\end{array}$ & 0.47 & 0.53 \\
\hline $\begin{array}{l}\text { Retention for seed for } \\
\text { next season }\end{array}$ & $13(13.75)$ & $3(3.75)$ & $\begin{array}{c}64 \\
(80.00)\end{array}$ & 0.56 & 0.44 \\
\hline $\begin{array}{l}\text { Storage of harvest } \\
\text { products }\end{array}$ & $14(17.50)$ & $6(7.50)$ & $\begin{array}{c}60 \\
(75.00)\end{array}$ & 0.55 & 0.45 \\
\hline $\begin{array}{l}\text { Selling to market } \\
\text { during financial needs }\end{array}$ & $18(22.50)$ & $59(73.75)$ & $3(3.75)$ & 0.24 & 0.76 \\
\hline $\begin{array}{l}\text { Decision in quantity to } \\
\text { be sold for financial } \\
\text { support }\end{array}$ & $17(21.25)$ & $9(11.25)$ & $\begin{array}{c}54 \\
(67.50)\end{array}$ & 0.55 & 0.45 \\
\hline $\begin{array}{l}\text { Separation of produces } \\
\text { for household use }\end{array}$ & $14(17.50)$ & $59(73.75)$ & $7(8.75)$ & 0.22 & 0.78 \\
\hline $\begin{array}{l}\text { Carrying the produces } \\
\text { to sale in market }\end{array}$ & $7(8.75)$ & $61(76.25)$ & $\begin{array}{c}12 \\
(15.00)\end{array}$ & 0.16 & 0.84 \\
\hline $\begin{array}{l}\text { Management of } \\
\text { revenue generated } \\
\text { from sale }\end{array}$ & $12(15.00)$ & $62(77.50)$ & $6(7.50)$ & 0.19 & 0.81 \\
\hline \multicolumn{4}{|c|}{ Average Participation Index } & 0.42 & 0.58 \\
\hline
\end{tabular}


Fig.1 Map of Mizoram district with location of the study village
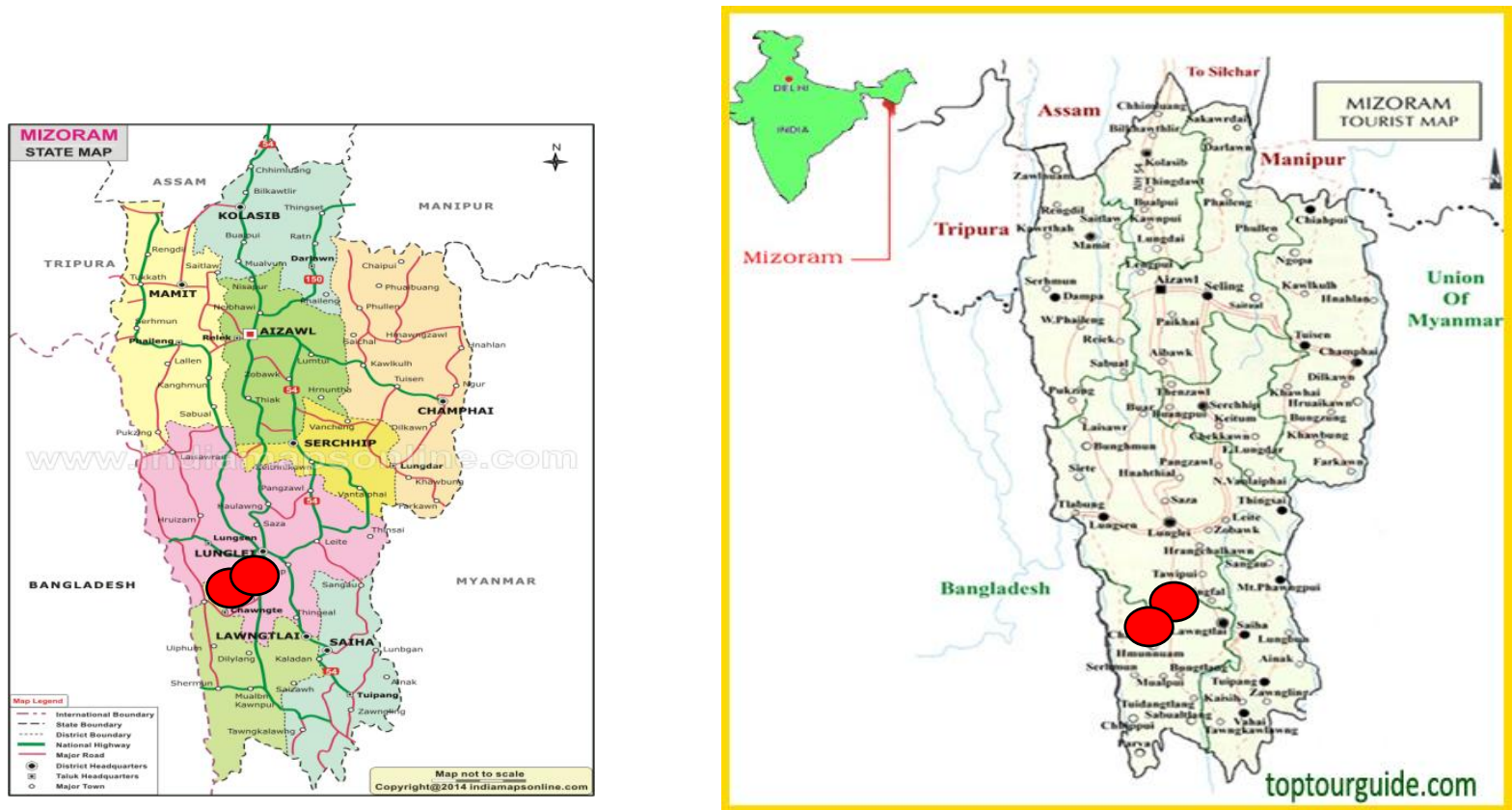

Fig.2 Comparative picture of male and female participation in agriculture and Animal husbandry activities

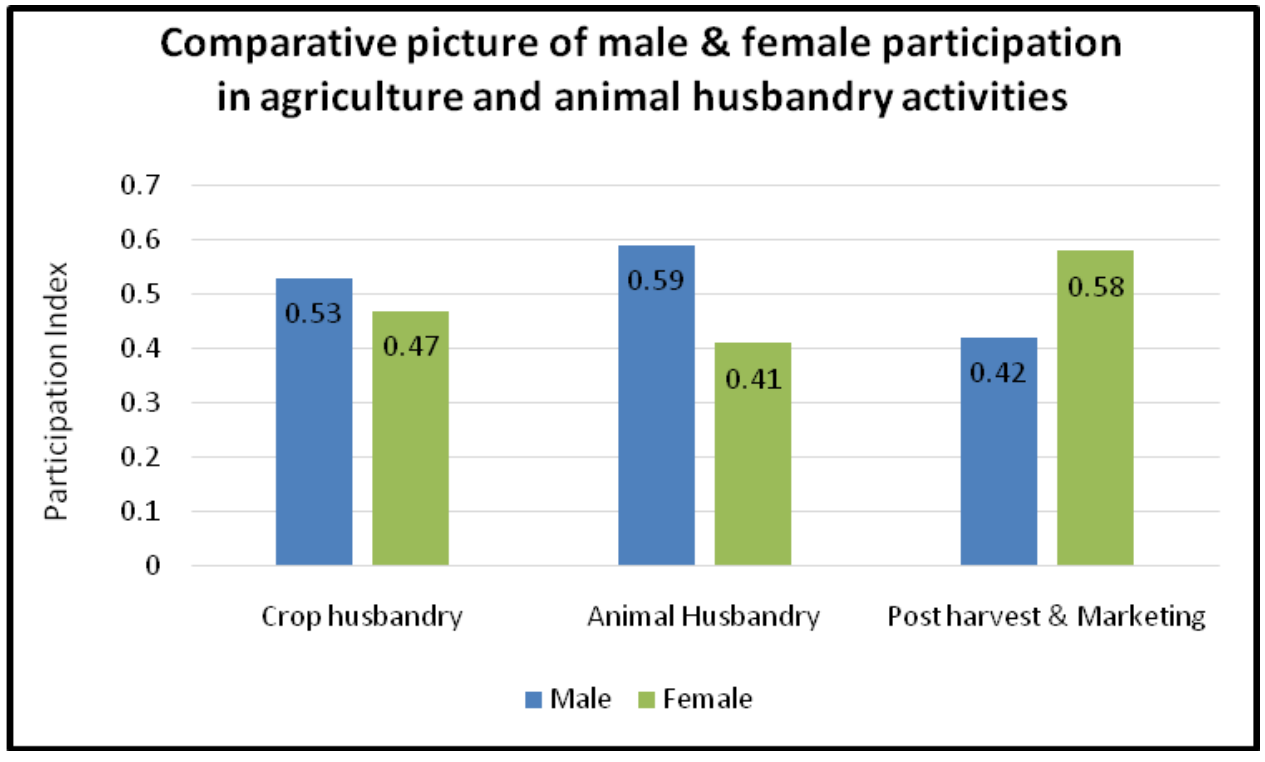

The result in the Table 5 shows that regarding different post-harvest and marketing activities female participation is more in case of cleaning of harvest products (Participation Index $=0.91$ against 0.09 of male); drying of harvest products (Participation Index $=0.81$ against 0.19 of male); milling of harvest products (Participation Index $=0.86$ against 0.14 of male); processing of produce (Participation Index $=0.89$ against 0.11 of male); retention for consumption and household consumption (Participation Index $=0.53$ against 0.47 of male); selling to 
market during financial needs(Participation Index $=0.76$ against 0.24 of male); separation of produces for household use (Participation Index $=0.78$ against 0.22 of male) carrying the produces to sale in market (Participation Index $=0.84$ against 0.16 of male) and management of revenue generated from sale (Participation Index $=0.81$ against 0.19 of male). All other activities although are predominantly undertaken by the male, but it is seen that Wilcoxon $(\mathrm{Z})$-value is not significant $(\mathrm{p}=0.518)$ which indicates that although there is difference in participation level in individual activities but on an average participation level of female and male are statistically at par.

The Figure 2 shows that in crop husbandry and animal husbandry the participation of male ( $\mathrm{PI}=0.53$ and 0.59 in two villages) is more as compared to female (PI=0.47 and 0.41in respective two villages). But in post-harvest and Marketing the participation of female (PI=0.58) are more than that of male (PI=0.42).

The interference can be drawn from the findings that in tribal farm families, some of the activities are predominantly undertaken by male and some others are by female. On an average female participation is more in case of postharvest management but less in case of agriculture and livestock rearing. Participation in agriculture and livestock rearing activities also enhance the economic empowerment of the females. It is a matter of satisfaction that both male and female in Mizoram are having statistically same level of participation. However, it should be ensured that the economic benefit of participation in activities should accrue to female also.

\section{Acknowledgement}

Authors are thankful to all the respondent of Hnahthial and Thiltlang village of Lunglei District in Mizoram for their active participation during the study.

\section{References}

Aggarwal, A.K. 2008. Social classification: The need to update in the present scenario. Indian J Community Med., 33:50-1.

Bihari, B., R. Kumar, K. Prasad and Sundarambal, P. 2012. Role Performance and Knowledge Level of Tribal Women Farmers in Meghalaya. Indian Res. J. Ext. Education. 12 (1): 60-63.

Chauhan, M.N. 2012. Contribution of the tribal farm women in livestock management. Agriculture Update. Vol.7. Issue 1\& 2:57.

Chauhan, N.M. 2011. Role performance of tribal farm women in agricultural and animal husbandry in Gujarat. Karnataka J. Agric. Science, 24 (5): 672-674.

Ghosh, P.K., C. Sahoo and Rath, S. 2010. Traditional Agricultural Wisdom for Sustainability in Tribal Areas. Orissa Review.

Kuppuswamy, B. 1981. Manual of Socioeconomic status scale (Urban), Manasayan, Delhi.

Nidhees, K.B. 2010. Agriculture Knowledge and perception in tribal communities. Indian Journal of Traditional Knowledge. Vol 9(3): 531- 535.

Parikh, U and Trivedi, G. 1964. Manual of socio-economic status scale (Rural), Manasayan, Delhi.

\section{How to cite this article:}

Senjit Singh Ashem, Tarun Kumar Das, Prabhat Kumar Pal and Lalmuanzovi. 2018. Roles of Gender in Agriculture and Livestock Production among Tribal Farm Families in Lunglei District of Mizoram in North East Region, India. Int.J.Curr.Microbiol.App.Sci. 7(08): 2498-2506. doi: https://doi.org/10.20546/ijcmas.2018.708.253 